\title{
Germination Studies and Early Seedling Growth of Sphenostylis stenocarpa (Hochst. Ex A. Rich.) Harms Following Some Pretreatment Protocol for Enhanced Germination
}

\author{
Sam, S.M. \\ Department of Biological Sciences, Akwa Ibom State Universty, Ikot Akpaden
}

Correspondence Author: Sam, S.M, Department of Biological Sciences, Akwa Ibom State Universty, Ikot Akpaden.

E-mail:- sundaysam@aksu.edu.ng

Received date: 18 February 2019, Accepted date: 5 April 2019, Online date: 26 April 2019

Copyright: $\odot 2019$ Sam, S.M, This is an open-access article distributed under the terms of the Creative Commons Attribution License, which permits unrestricted use, distribution, and reproduction in any medium, provided the original author and source are credited.

Abstract
Germination and early seedling growth of Sphenostylis stenocarpa were studied to determine the most effective
method of breaking the seed coat-dormancy. Sphenostylis stenocarpa seeds were treated with concentrated
sulphuric acid $\left(\mathrm{H}_{2} \mathrm{SO}_{4}\right)$, nitric acid $\left(\mathrm{HNO}_{3}\right)$, hydrochloric acid $(\mathrm{HCl})$, nicking and hot water for $5,10,15$ and 20
minutes. Chemical scarification with concentrated sulphuric acid at 5 seconds significantly $(\mathrm{P}<0.05)$ enhanced the
germination and growth of Sphenostylis stenocarpa. The ratio of occurrence of small size (SS) to large size (LS) seeds
Sphenostylis stenocarpa was $1: 4$. The small size seed has an average weight of $0.24 \pm 0.05 \mathrm{ghile}$ the large size seed
has an average weight of $0.36 \pm 0.08 \mathrm{~g}$. This study shows that sulphuric acid scarification is an effective method for
breaking seed coat-imposed dormancy in Sphenostylis stenocarpa

Keywords: Germination, Growth, Pretreatment, Sphenostylis stenocarpa

\section{INTRODUCTION}

It is widely accepted that temperature regulates both dormancy and germination and that light regulates germination; however, it is a matter of debate whether light is also a regulator of dormancy (Vleeshouwers et al., 1995; Casal and Sanchez, 1998; Pons, 2000; Baskin and Baskin, 2004; Fenner and Thompson, 2005; Kucera, et al, 2005). Light has been considered both to stimulate germination (Vleeshouwers et al., 1995) and to terminate dormancy (Benech-Arnold et al., 2000; Batlla et al., 2004).

Underutilized crops are indigenous, relatively common in specific areas, available, accessible, well-adopted, easy and cheap to produce, and culturally linked to the people who use them traditionally (Oniango et al., 2006; Okigbo, 1973; Padulosi et al., 2003; Jaenicke and Pasiecznik, 2009). Their cultivation and utilization usually draw on indigenous knowledge. The ecotypes and landraces of these species are cultivated less than in the past. They are rarely found in urban markets. They cannot compete with crops which now dominate the world's food. They are hardly represented in ex situ genebanks, so efforts to characterize them depend on the limited available and loosely representative diversity (Padulosi and Hoeschlie- Zeledon, 2004). They are therefore usually ignored by policy makers probably because their economic value is not apparent (Stifel, 1990) and hence are excluded from the development agenda by research institutions. However, underutilized crops are important as household food and their contribution to food security is unquestionably significant (Oniango et al., 2006; Naylor et al., 2004).

Grain legumes constitute the main source of protein in the diets of the average Nigerian home. The most important ones are cowpea (Vigna unguiculata), groundnut (Arachis hypogea) and lima bean (Phaseolus lunatus). However, there are other pulses that could help meet dietary needs but are cultivated only in localized areas and used less (Klu et al., 2001). These underexploited legumes include African yam bean (Sphenostylis stenocarpa), Bambara groundnut (Vigna subterranea) and pigeon pea (Cajanus cajan)

Sphenostylis stenocarpa is a leguminous crop belonging to the family Fabaceae, sub-family papilonoidae, tribe Phaseoleae, sub-tribe Phaseolionae and genus Sphenostylis (Okigbo, 1973; Allen and Allen, 1987). It is most economically important among the seven species of Sphenostylis (Porter, 1992) and it is one of the most important tuberous legumes. The domestication, cultivation and distribution of the crop are very evident in the tropics of Africa (Okigbo, 1973; Porter, 1992; Anochili, 1984; Opara and Omaliko, 1997) where it had been reported to exhibit very high diversity. African yam bean is distributed throughout 
Citation: Sam, S.M, Germination Studies and Early Seedling Growth of Sphenostylis stenocarpa (Hochst. Ex A. Rich.) Harms Following Some Pretreatment Protocol for Enhanced Germination. Australian Journal of Basic and Applied Sciences, 13(4): 50-56. DOI: 10.22587/ajbas.2019.13.4.8

most tropical Africa (Anonymous, 1979; Porter, 1992). It is found in forest, open and wooded grasslands, rocky fields as well as marshy grounds, occurring both as a weed and cultivated crop (Duke et al., 1977; Porter, 1992). It grows on a wide range of soils including acid and highly leached sandy soils at altitudes from sea level to 1,950m (Duke et al., 1977; Anonymous, 1979). This work is therefore aimed at determining a highly effective pretreatment protocol for breaking the seed coat-imposed dormancy in Sphenostylis stenocarpa.

\section{Sources and Collection of Seeds}

\section{MATERIALS AND METHODS}

The seeds of African yam bean- Sphenostylis stenocarpa (Hochst. ex.A. Rich) Harms were collected from local farmers in Use Offot, and Nsukara Offot in Uyo Local Government Area of Akwa Ibom State. The seeds were identified by Prof. (Mrs.) M. E. Bassey, a taxonomist in the Department of Botany and Ecological Studies, University of Uyo. The seeds were extracted from the dried pods. Observation showed that two sizes of seeds and two colours were present, a small size (SS) and a large size (LS), brown and white. The weight of each seed was also determined. Premature and infected seeds were discarded, and selected seeds were taken to the laboratory for preservation and germination studies. Seeds from both sources (Use Offot and Nsukara Offot) were pooled together and the brown colour seeds were used for the studies.

\section{Viability, Germination and Growth Studies}

Viability of 3 replicates of 26 seeds was assessed using the tetrazolium chloride (TZ) staining technique (ISTA, 2003). Seeds were placed in $1 \%$ tetrazolium chloride solution at $30^{\circ} \mathrm{C}$ and darkness for 24 hours. Seeds were then cut in half and examined. Only uniformly stained red/dark pink embryos were considered 'viable'.

The seeds were surface sterilized by soaking in $5 \%$ sodium hypochlorite $(\mathrm{NaOcl})$, solution for 5 minutes and subsequently rinsed thoroughly with sterilized water prior to applying any treatment. Germination and growth experiments were conducted using three replications of 20 seeds per treatment. Seeds were scarified with each of concentrated $\mathrm{Nitric}_{\text {acid }}\left(\mathrm{HNO}_{3}\right)$, Sulphuric acid $\left(\mathrm{H}_{2} \mathrm{SO}_{4}\right)$, Hydrochloric acid $(\mathrm{HCl})$, Nicking and Hot water $\left(100^{\circ} \mathrm{C}\right)$ for $5,10,15$ and 20 seconds. Seeds were placed on double layered Whatman No.1 filter paper moistened with $10 \mathrm{ml}$ of distilled water in $15 \mathrm{~cm}$ diameter Petri dishes. Percentage germination at two days interval, seedling height, leaf area, number of roots, length of longest roots and fresh weight were determined four weeks after the treatments. A seed was considered germinated when the tip of the radicle had pierced through and grown free of the seed coat (Wiese and Binning, 1987; Auld et al., 1988).

\section{Germination Studies in the Field}

In order to find out the responses of Sphenostylis stenocarpa seeds in the field, bush was cleared and ridges made in the Postgraduate Research Farm of the University of Uyo, Uyo. Twenty seeds were surface sterilized by steeping in 5\% sodium hypochlorite $(\mathrm{NaOCl})$ solution for 5 minutes and subsequently rinsed thoroughly with sterilized water. Seeds scarified with $\mathrm{HNO}_{3}$, $\mathrm{H}_{2} \mathrm{SO}_{4}, \mathrm{HCl}$, Nicked and treated with Hot water $\left(100^{\circ} \mathrm{C}\right)$ for $5,10,15$ and 20 seconds were planted $15 \mathrm{~cm}$ apart on ridges. Ridges were weeded as need arose. Seed emergence was recorded daily.

\section{Sampling of Collected Seeds}

\section{RESULTS}

In all the samples investigated, the ratio of occurrence of small size, (SS) to large size (LS) seed was within the range of 1:4 to 1:6 (Table 1). The small size seed has an average weight of $0.24 \pm 0.05 \mathrm{~g}$ while the large size seed has an average weight of $0.36 \pm 0.08 \mathrm{~g}$. Both types were brown in colour and the mixed population was used for the study.

\section{Germination and Growth Studies}

The results of germination and growth studies are presented in Figures 1 to 6.

In Figure 1, sulphuric acid and hydrochloric acid significantly $(\mathrm{P}<0.05)$ enhanced the percentage germination of the seeds at 5 and 20 seconds respectively. In Figure 2, sulphuric acid significantly $(\mathrm{P}<0.05)$ increased seedlings height at 5 seconds. Figure 3 showed that hydrochloric acid significantly $(\mathrm{P}<0.05)$ increased leaf area at 20 seconds. Figure 4 show that hydrochloric acid significantly $(\mathrm{P}<0.05)$ increased number of roots at 20 seconds. Figure 5 show that sulphuric acid significantly $(\mathrm{P}<0.05)$ increased the length of longest roots at 20 seconds. Hot water significantly $(\mathrm{P}<0.05)$ increased fresh weight at 10 seconds $($ Figure $6)$.

Table 1: The ratio of small and large size seeds of Sphenostylis stenocarpa

\begin{tabular}{|c|c|c|c|}
\hline $\begin{array}{c}\text { Total of five } \\
\text { collections }\end{array}$ & Small seeds (SS) & Large seeds (LS) & Ratio of SS:LS \\
\hline 69 & 10 & 59 & $1: 6$ \\
\hline 61 & 13 & 48 & $1: 4$ \\
\hline 46 & 7 & 39 & $1: 6$ \\
\hline 63 & 13 & 50 & $1: 4$ \\
\hline 60 & 12 & 48 & $1: 4$ \\
\hline
\end{tabular}




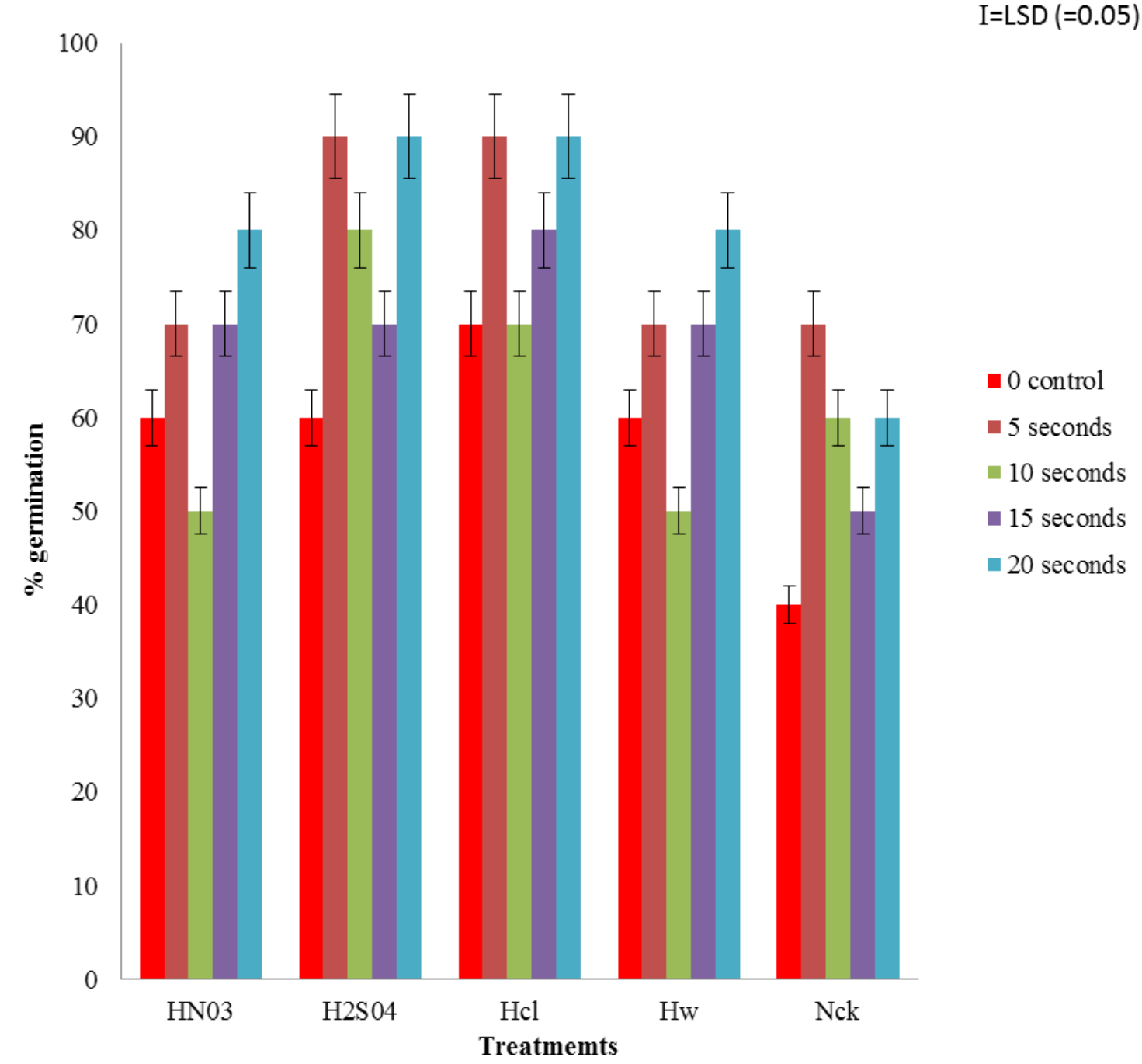

Figure 1: Effects of scarification, hot water and nicking on germination of Sphenostylis stenocarpa

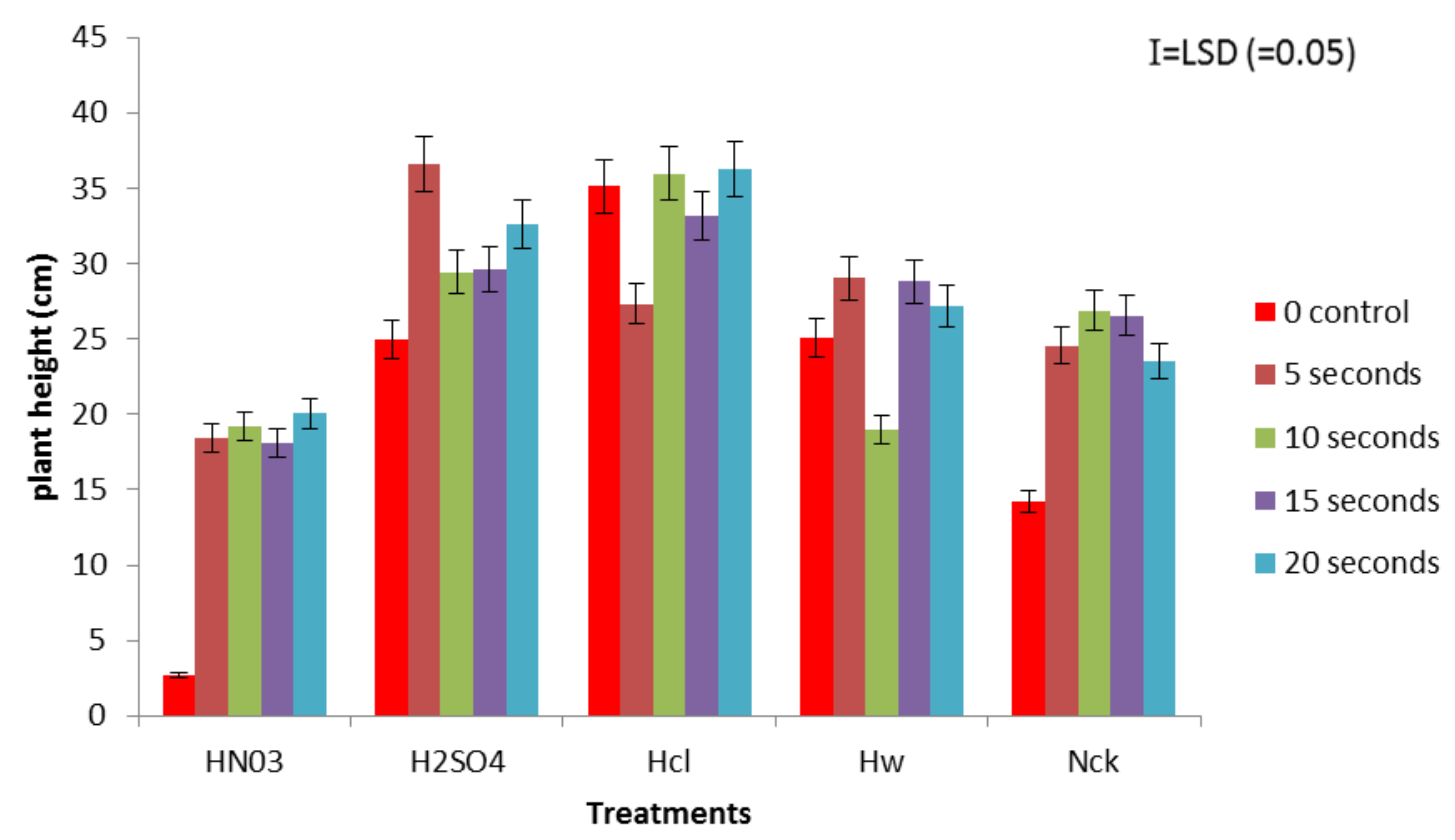

Figure 2: Effects of scarification, hot water and nicking on seedlings height of Sphenostylis stenocarpa 


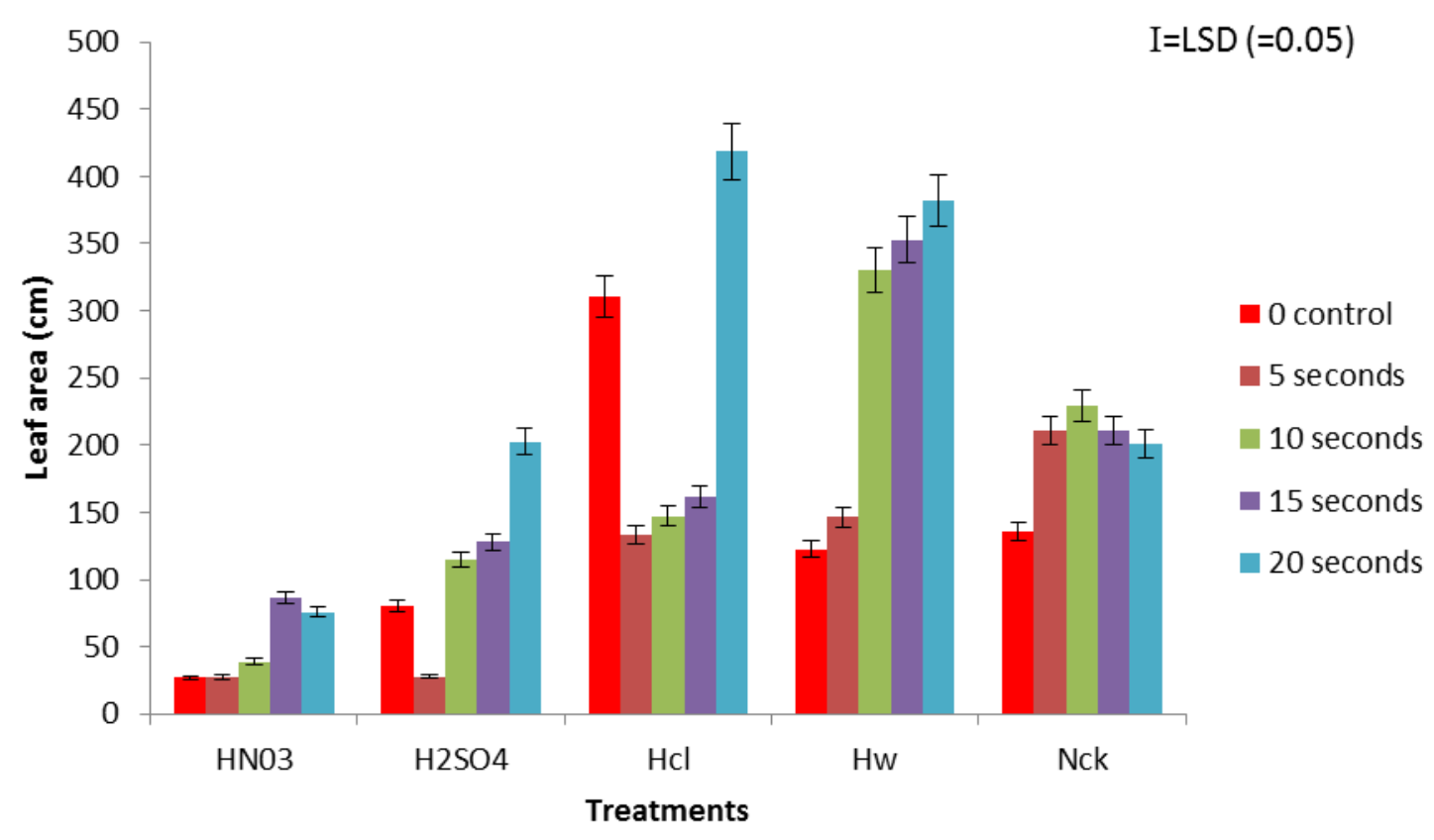

Figure 3: Effects of scarification, hot water and nicking on leaf area of Sphenostylis stenocarpa

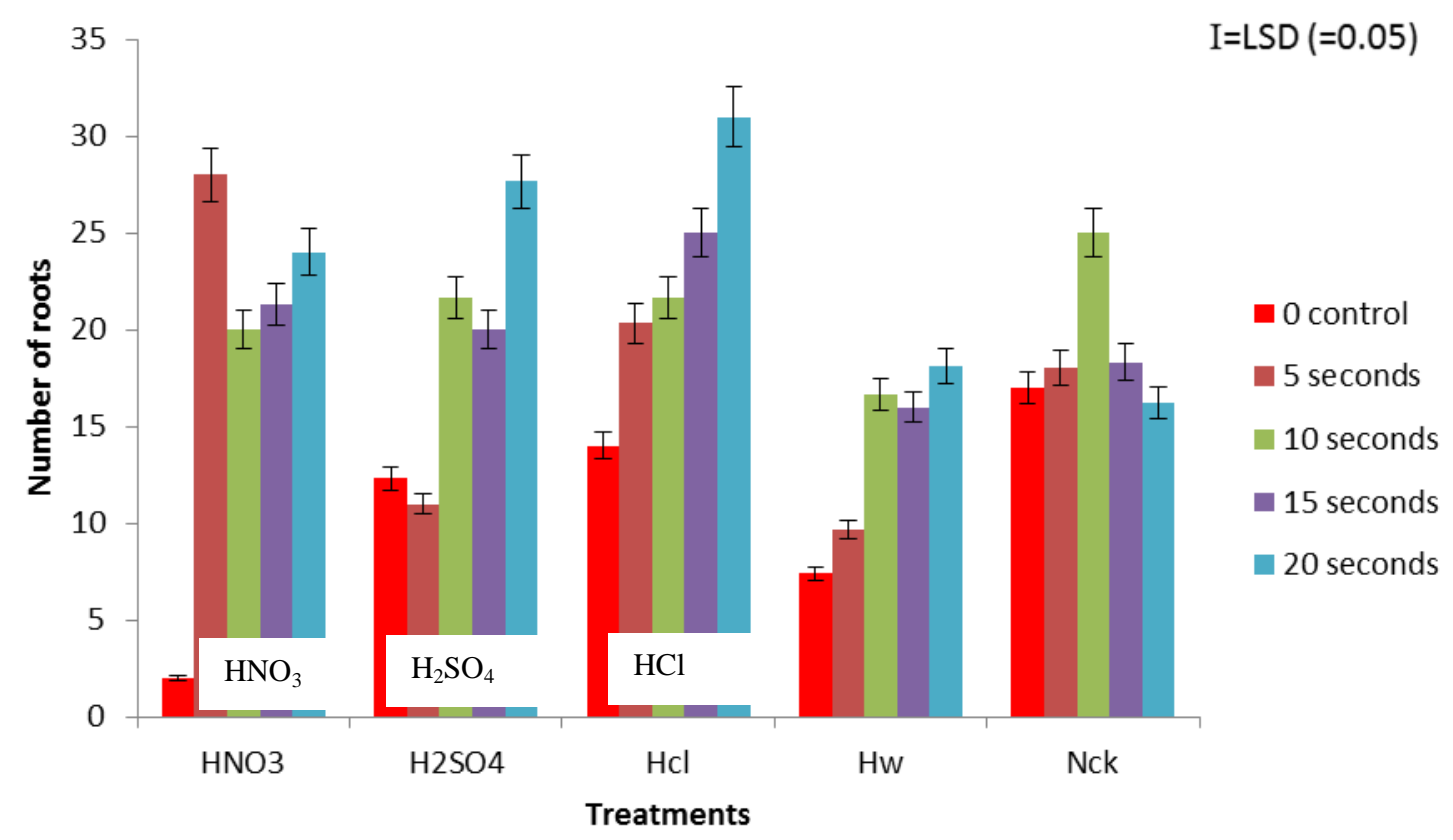

Figure 4: Effects of scarification, hot water and nicking on number of roots of Sphenostylis stenocarpa 


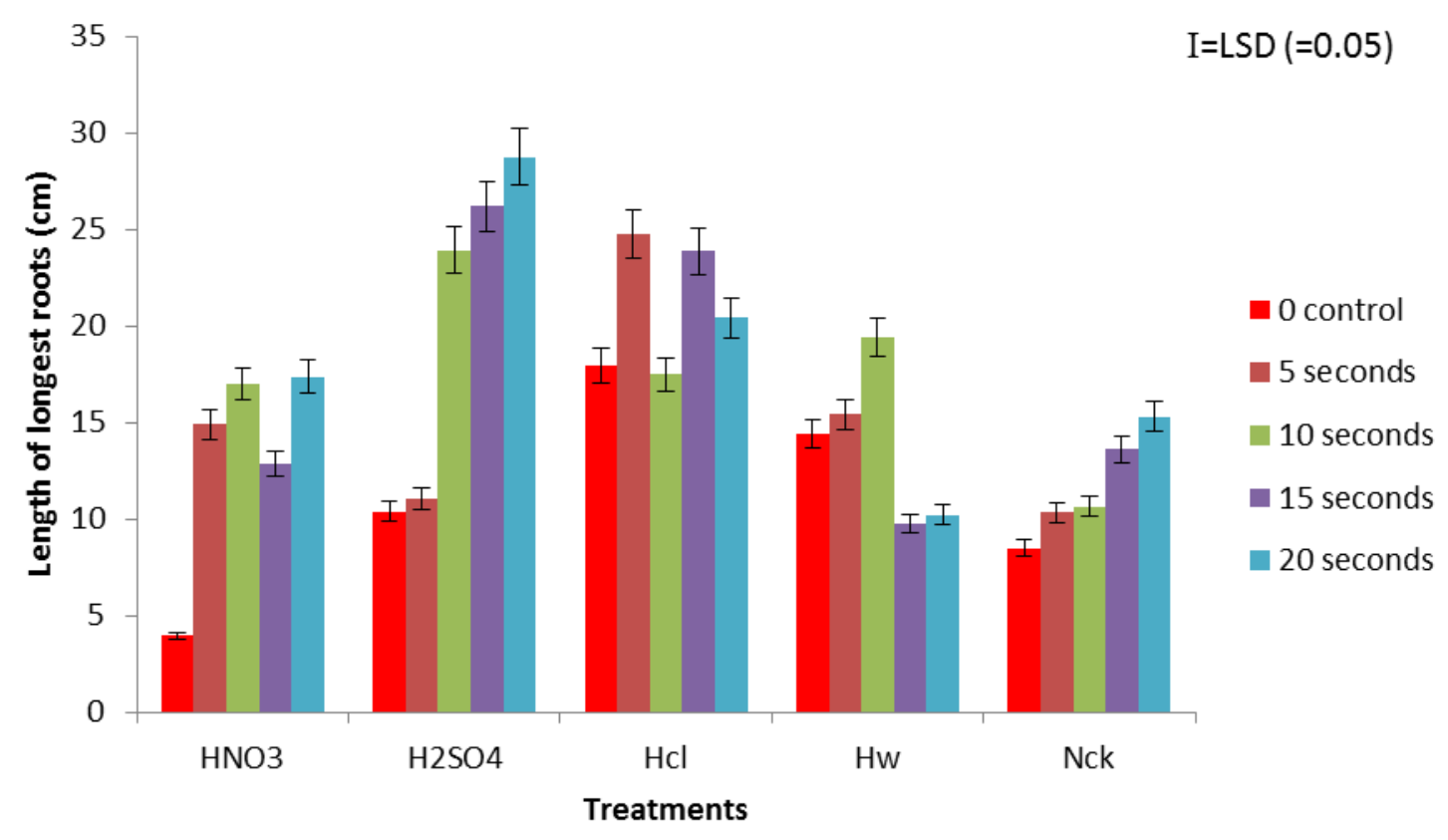

Figure 5: Effects of scarification, hot water and nicking on length of longest roots of Sphenostylis stenocarpa

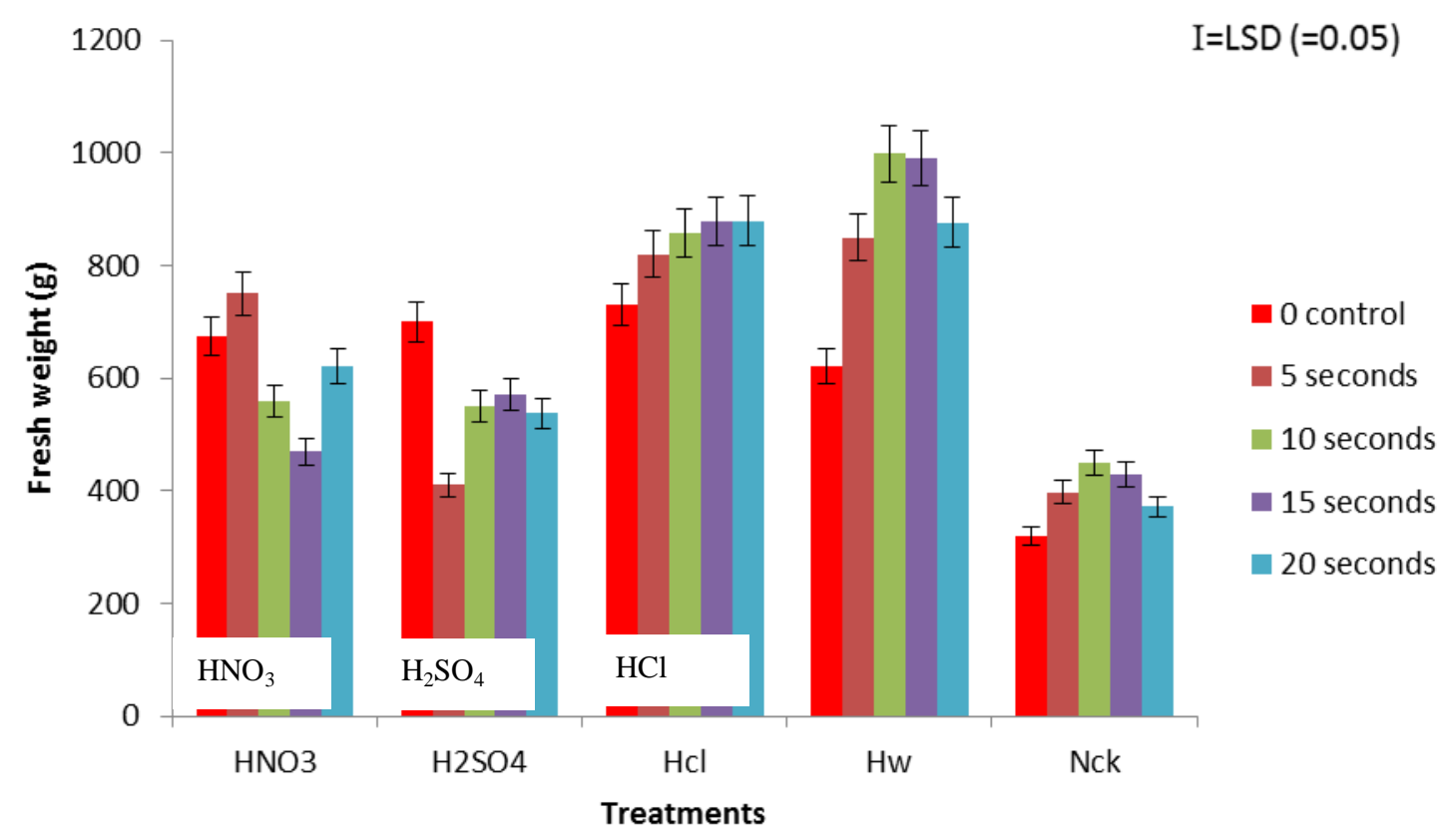

Figure 6: Effects of scarification, hot water and nicking on fresh weight of Sphenostylis stenocarpa

Legend:

$\mathrm{HNO}_{3}=$ Nitric acid

$\mathrm{H}_{2} \mathrm{SO}_{4}=$ Conc. Sulphuric acid

$\mathrm{HCl}=$ Hydrochloric acid

$\mathrm{HW}=$ Hot water

NCK $=$ Nicking

\section{DISCUSSION}

Proper seed germination and growth are indispensable for the continued existence of any plant. Germination, sensu stricto includes those events commencing with imbibition or uptake of water by the quiescent dry seed and culminates with the elongation of the radicle (Bewley and Black, 1994). Visible evidence of the completion of germination is usually protrusion of the radicle through the seed structures surrounding the embryo (such as the testa and endosperm, or megagametophyte). However, some seeds fail to complete germination under seemingly favorable conditions, even though they are viable. Such seeds are said to be dormant. Dormancy in seeds has to be broken, irrespective of the type, for effective germination and vigorous growth. 
Citation: Sam, S.M, Germination Studies and Early Seedling Growth of Sphenostylis stenocarpa (Hochst. Ex A. Rich.) Harms Following Some Pretreatment Protocol for Enhanced Germination. Australian Journal of Basic and Applied Sciences, 13(4): 50-56. DOI: 10.22587/ajbas.2019.13.4.8

Chemical scarification with concentrated sulphuric acid $\left(\mathrm{H}_{2} \mathrm{SO}_{4}\right)$ at 5 seconds significantly $(\mathrm{P}<0.05)$ enhanced the germination and growth of Sphenostylis stenocarpa seeds followed by hydrochloric acid at 20 seconds. The strong inhibitory effect of the seed coat on seed germination may be caused by several possible mechanisms, including mechanical constraint, prevention of water and oxygen uptake, and retention or production of chemical inhibitors (Taiz and Zeiger, 2002). The integument breaking or softening, for instance, is needed to remove dormancy imposed by seed coat hardness or impermeability. Therefore, chemical scarification (softening the hard seed coat) with concentrated $\mathrm{H}_{2} \mathrm{SO}_{4}$ was used to remove exogenous dormancy. In the present study, a significant number of $S$. stenocarpa seeds that had been treated with $\mathrm{H}_{2} \mathrm{SO}_{4}$ germinated. The response of $S$. stenocarpa seeds to $\mathrm{H}_{2} \mathrm{SO}_{4}$ as a method for enhancing germination and growth was consistent with other studies (Keshtkar et al., 2008; Hermansen et al., 2000; Nadjati et al., 2006; Rahnama-Gahfarokhi and Tavakol-Afshar, 2007).

This study indicated that chemical scarification methods are effective in rendering seeds of S. stenocarpa permeable, leading to germination up to $90 \%$ after 6 days. This confirms the earlier reports of Onyekwelu (1990). A previous study by Lemos-Filho et al. (1997) showed that mechanical and chemical scarifications are more effective in breaking the hard seed coat of Senna multijuga. It was equally observed in this study that within the scarification methods, chemical scarification with sulphuric and nitric acids, as well as mechanical scarification were more effective, confirming earlier reports by Ayisire et al. (2008) in Piliostigma thonningii, Lacerna et al (2004) in Senna multijuga (Caesalpinoideae) and Plathymenia reticulata (Mimosoideae). Sulphuric acid had the highest germination percentage (90\%), followed by nitric acid scarified seeds with $80 \%$.

\section{CONCLUSION}

These results revealed that seed dormancy in S. stenocarpa is mainly due to the hard seed coat, which can be broken effectively by chemical scarification, especially by sulphuric acid preatreatment. It is hoped that the results of this study will provide useful information for domestication and large scale plantation development, and in environmental conservation efforts.

\section{ACKNOWLEDGEMENT}

Author acknowledges the financial assistance from the Tertiary Education Trust Fund (TETFUND) and the technical assistance of Mr. D. N. Bala of the Departmment of Pharmacognosy and Natural Medicine, University of Uyo, Uyo.

\section{REFERENCES}

Allen, O. N. and Allen, E. K. (1987). The Leguminous. A Source Book of characterization, uses and Nodulation, London: Macmillan Publishers' Ltd p. 620.

Anochili, B. C. (1984). Tropical Agricultural Handbook Food Crop Production. London, Macmillan publishers, pp. 48-50. Doi:ajps.2011.370.375

Anonymous (1979). Tropical Legumes: Resource for the Future. Washington, D. C. National Academy of Sciences, p. 331. DOI: https://doi.org/10.17226/19836

Asiyire, B.E., Akinro, L.A., and Amoo, S.O. (2008). Seed germination and in vitro propagation of Piliostigma thonningii-an important medicinal plant. African Journal of Biotechnology. 8(3): 401-404. Retrieved from https://www.ajol.info/index.php/ajb/article/view/59824 on 2nd October, 2018

Auld, D. L. Bettis, B. L., Crock, J. E. and Kephart, D. (1988). Plannting Data and Temperature Effects on Germination, and Seed Yield of Chickpea. Agronomy Journal, 80: 909-914. Retrieved from Profdoc.um.ac.ir/articles/a/1019579.pdf on 20 ${ }^{\text {th }}$ May, 2018

Baskin. J. M., and Baskin C. C. (2004). A Classification System for Seed Dormancy. Seed Science Research 14: 1 16.Doi:10.1.1.847.7098

Benech -Arnold R. L., Sanche, R. A., Forcella, F. Kruk, C. B. and Ghersa, C. M. (2000). Environmental Control of Dormancy in Weed Seed Banks in Soil. Field Crops Research 67:105-122. Doi:10.1371/journal.pone.0071457

Bewley, J.D. and Black, M. (1994) Seeds: Physiology of development and germination (2nd edition). New York, Plenum Press. p445.

Casal, J. J. and Sanchez, R. A. (1998). Phytochromes and seed germination. Seed Science Research 8: $317-329$. https://doi.org/10.1017/S0960258500004256

Duke, J. A., Okigbo, B. N., and Reed, C. F. (1977). African Yam Bean, Sphenostylis stenocarpa (Hochst ex.A. Rich). Tropical Grain Legume Bulletin, 10: 4-5. Retrieved from htt://www.nzdi.org/gsdlmod?10.10.10 on $5^{\text {th }}$ December, 2018

Fenner, M. and Thompson, K. (2005). The Ecology of Seeds. Cambridge, UK: Cambridge University Press. pp. 121-124

Hermanseu, L. A., Auryea, M. L. and White, T. L. (2000). Viability in Seed Coat Dormancy in Dimorphendra Moltis. Seed Science and Technology, 28: 567 - 580.

International Seed Testing Association (ISTA) (2003). Working Sheetss on Tetrazolium Testing. Vols I and II. ISTA, Bassersdorf, Switerland. pp. 8-10. International Tree Journal. 6(1):59-66.

Jaenicke, H. and Pasiecznik, N. (2009). Making most of Underutilized Crops. Leiga Magazine 25:11 - 12.

Keshtkar, A. R.; Keshtakar, H. R., Razavi, S. M. and Dalfardi, S. (2008). Methods to Break Seed Dormancy of Astragalus cyclophyllon. African Journal of Biotechnology Vol. 7 (21), pp. 3874 - 3877.

Klu, G. Y. P., Amoatey, H. M., Bansa, D. and Kumaga, F. K. (2001). Cultivation and Use of African Yam Bean (Sphenostylis stenocarpa) in the Volta Region of Ghana. Journal of Food Technology in Africa, 6 (3): 74 - 77 . Retrieved from https://www.ajol.info/index.php/jfta/view/19292 on 2nd October, 2018

Kucera, B., Cohn, M. A. and Leubner- Metzger, G. (2005). Plant Hormone Interactions during Seed Dormancy Release and Germination Seed Science Research 15: 281 - 307. 
Citation: Sam, S.M, Germination Studies and Early Seedling Growth of Sphenostylis stenocarpa (Hochst. Ex A. Rich.) Harms Following Some Pretreatment Protocol for Enhanced Germination. Australian Journal of Basic and Applied Sciences, 13(4): 50-56. DOI: 10.22587/ajbas.2019.13.4.8

Lacerna, D.R.; Lemos-Filho, J.P., Goulat, M.F., Ribeiro, R.A. and Lovato, M.B. (2004). Seed dormancy variation in natural populations of two tropical leguminous tree species: Senna multijuga (Caesalpinoideae) and Plathymenia reticulata (Mimosoideae). Seed Science Research. 14: 127-135.

Lemos-Filho, J.P., Guerra, S.T.M., Lovato, M.B. and Scotti, M.R.M. (1997). Germinação de sementes de Senna macranthera, Senna multijugae tryphnodendron polyphyllum. Pesquisa Agropecuária Brasileira 32: 357- 361.

Nadjafia, F., Bannayam, M., Tabrizia, L. and Rastgoo, M. (2006). Seed Germination and Dormancy Breaking Techniques for Ferula gulmmosa and Teucrium polium. Journal of Arid Environments, 64:542 - 547

Naylor, R. 1. Falcon, W. P., Goodman, R. M., John, M. M., Sengooba, T., Tefera, H. and Nelson, R. J. (2004). Biotechnology in the Developing World: a case for increased investment in orphan crops. Food Policy, 29:15-44.

Okigbo, B. N. (1973). Introducing the Yam Bean (Sphenostylis stenocarpa) (Hochst ex. A. Rich) Harms. In: Processing of the $1^{\text {st }}$ 11TA Grain Legume Improvement Workshop 29 October - 2 November, Ibadan. pp. 224 - 238.

Oniango, R. K., Shiundu, K., Manundu, P. and Johns, T. (2006). Diversity, Nutrition and Food Security: the case of African Leafy Vegetatables. In: Ralli, S. B., Hoeschle-Zeledon, I., Swaminathan, M. S. and Frison, E. (Ed.). Hunger and Poverty: The Role of Biodiversity. Report of an International Consultation on the role of Bidiversity in achieving the UN Millennium Development Goal of Freedom from hunger and poverty. Chennai India, April 18 - 19, 2005. M.S. Swaminathan Research foundation, Chennai, India. pp. $83-100$.

Onyekwelu, S. S. (1990). Germination studies in Tetrapleura tetraptera. International Tree Journal. 6(1):59-66. https://doi.org/10.1080/01435698.1990.9752871

Opara, D. A. and Omaliko, C. P. E. (1997). Reponse of African Yam Bean (Sphenostylis stenocarpa) to Sowing Date and Plant Density. Indian Journal of Agricultural Science. 67:220 - 221.

Padulosi, S. and Hocshlle-Zeledon, I. (2004). Underutilized plants species: What are they? Leisa Magazine, $20: 5$ - 6.

Padulosi, S., Noun, J., Giuliani, A. Shuman, F., Rojas, W. and Ravi, B. (2003). Realizing the Benefits in Neglected Underutilized Plant Species through Technology Transfer and Human Resources Development. In: Norway/UN Conference on Technology Transfer and Capacity Building. pp. 117 - 127.

Pons, T. L. (2000). Seed Responses to Light. In: Fenner, M. (ed.) Seeds - the Ecology of Regeneration in Plant Communities. Wallingford, UK: CAB International, $237-260$.

Porter, D. (1992). Economic Botany of Sphenostylis (Leguminosae). Economic Botany, 46 (3): 262-275. Retrieved from https://www.jstor.org/stable/4255442 on 10th November, 2018

Rahnam - Ghahfarokhi, A. and Tavakol-Afshari, R. (2007). Methods for Dormancy Breaking and Germination of Galbanum Seeds (Ferula gummosa). Asian Journal of Plant Science, 6(4): 611 - 616.

Stifel, L. D. (1990). The Genetic Resources. In: Monti, L. M. (Eds). Cowpea Genetic Resource No.9. International Institute of Tropical Agriculture, Ibandan, pp $3-4$.

Taiz, L. and Zeiger, E. (2002). Plant Physiology. Abscisic Acid: a Seed Maturation and Antistress Signal, $3^{\text {rd }}$ Ed., Sunderland; Sinauer Association Inc., pp 538 - 558.

Vleeshouwers, L. M., Bouwmeester, H. J. and Karssen, C. M. (1995). Redefining Seed Dormancy; an attempt to integrate Physiology and Ecology. Journal of Ecology, 83: 1031-1037. 